\title{
ISSUES AND CHALLENGES WITH RENEWABLE ENERGY IN OMAN
}

\author{
Al Hatmi Y ${ }^{1}$, C.S. Tan ${ }^{2}$ \\ ${ }^{l}$ College of Engineering, Universiti Tenaga Nasional (UNITEN), Malaysia \\ alhatmi2012@gmail.com \\ ${ }^{2}$ Institute of Energy Policy and Research (IEPRe), Universiti Tenaga Nasional (UNITEN), Malaysia \\ chingsin@uniten.edu.my
}

\begin{abstract}
This paper provides a comprehensive review of energy sources in Oman as well as looking into the structures of the electricity sector in the Sultanate of Oman. The growing population and the spacing between housing units in the territory of Oman has became a major challenges to the government in generation planning due to its limited energy resources in the country. Hence, energy has become an important sector in Omani vision 2020. Renewable energy (RE) sources form a vital and strategic solution for the provision of electric power in the Sultanate; few studies have indicated that Oman is rich in solar and wind energy. However, this sector faces many challenges, and the development of RE is at a slow pace. This paper identify the issues and challenges of RE in Oman
\end{abstract}

Index Terms: Renewable Energy, Solar Power, Wind Energy, Oil and Gas, Electricity.

\section{INTRODUCTION}

Oman, like other Arab gulf countries, depends on oil and gas to produce electricity. However, these resources are not guaranteed to last forever, and are one of the energy security issues in the country. Some of the gulf countries have diversified their energy resources-for example, the United Arab Emirates has considered the nuclear and Renewable Energy (RE) as part of their electric generation and Qatar aims to generate $20 \%$ of its energy from renewable by 2024 with $1800 \mathrm{MW}$ of installed green capacity by 2020 - As for Oman, the progress of RE development is at a slow pace as currently the electricity generation is still depending on the oil and gas.

Two RE resources that are identified to be potential in Oman highlighted in most of the technical research done in Oman are solar and wind energy. Most of the technical research papers indicate that Oman is among the best areas in the world for solar energy as well as certain areas in Oman for wind energy. However, so far there is little progress in RE deployment in Oman. The slow development of RE is probably due to the lack of policy regulation in Oman as well as the limited budget to promote RE in Oman.

\section{COUNTRY OVERVIEW}

\subsection{Geographical Factor}

Oman is a country with an area of $309,500 \mathrm{sq}$. $\mathrm{km}$ on the south eastern coast of the Arabian Peninsula with a population of $3,090,150$. The annual population growth is estimated at $2 \%$ at present, with more than $27 \%$ of the Omani Population below 14 years of age and with $70.33 \%$ between ages of 15 and 64, which creates a significant challenge in terms of finding future employment opportunities. More than $30 \%$ of the population live in a large area, which includes much inhospitable land, living in small communities or living a nomadic existence [1].

\subsection{Social Indicator}

Oman is divided into 11 governorates, and each governorate is divided into many Willyiah, and each Willyiah has many small villages. The main challenge is the distance between Willyiahs and between villages. This means that there are a lot of expenses to provide these areas with electricity and link them to the main grid.

\subsection{Economic Indicator}

Oman is divided into 11 governorates, and each governorate is divided into many Willyiah, and each Willyiah has many small villages. The main challenge is the distance between Willyiahs and between villages. This means that there are a lot of expenses to provide these areas with electricity and link them to the main grid. Most of the industrial areas in Oman depend on gas. However, the gas production is not stable and may not be secure in the future, which will affect the government's development plans and annual budget.

Omani Vision 2020 seeks to reduce dependence on oil, diversify the economy and create new employment opportunities for all Omani citizens. The Vision 2020 also stresses on the promotion of technology transfer and the increased use of natural and renewable resources, with due regard to the social and natural environment, which gives priority to the following key aspects [2]. 
- Diversification away from oil and towards an exportoriented manufacturing industrial base; increasing the proportion of Omanis working in the target industrial companies.

- Promoting inward investment by foreign companies, with a number of incentives for new industrial companies.

- Promotion of clean energy technologies and the development of a conservation plan to protect the natural environment

- Improvement of the water supply, both for irrigation and for remote communities.

- Maximise earnings from the nation's oil resources, whilst extending reserves for future use.

- Provide power from the least cost sources to meet domestic, commercial and anticipated industrial demand.

While this Vision 2020 provides a clear path for all ministries and government agencies to follow, however, the development of RE is still at a slow pace.

\section{ENERGY INFRASTRUCTURE}

Energy is a critical foundation for economic growth and social progress. However, as the economy advances and human society requires more energy, the lack of fossil energy and its pollution of the environment has given rise to conflicts between energy provision, environmental protection and economic development [2].

On the other hand, the non-fixed price of gas and the oil volatility led to institutions and governments promoting research to find other energy resources with less environmental impact, sustainable, stability and low costs. Up to now, there is no effective alternative for oil and gas, but there are hybrid alternatives that can reduce big oil and gas attrition by mixing sources such as solar, wind and others. Continued efforts to find new techniques will ultimately allow Oman to dispense with gas and oil, which pollutes the environment and affects the ozone layer, and find sources of energy characterised by continuity.

\subsection{Fossil Energy}

The export of oil and gas is the foundation of the modern economy in Oman. They are also used to fuel industry and for domestic consumption, both directly and through electrical power generation. The domestic consumption is priced in relation to the opportunity costs from constraining experts [3]. Oman depends on gas and oil resources for almost all of its energy needs. However, the country's natural gas supplies are currently largely committed, and it may become a net importer soon.
Table -1: The yearly average production of crude oil and gas from 2000-2012

\begin{tabular}{|c|c|c|c|c|c|c|c|c|c|c|c|c|c|c|c|}
\hline & 8 & 8 & 踝 & है & & $\begin{array}{l}\omega \\
\delta \\
0\end{array}$ & ह & 5 & $\varepsilon$ & & $P$ & & $\frac{\tilde{e}}{0}$ & $\stackrel{\tilde{e}}{\varepsilon}$ & $\stackrel{\tilde{e}}{\sim}$ \\
\hline $\begin{array}{l}\text { Crude oil } \\
(1000 \\
\text { barrels per } \\
\text { day) }\end{array}$ & 草 & $\begin{array}{l}0 \\
u \\
0\end{array}$ & $\begin{array}{l}\infty \\
0 \\
\infty \\
\omega\end{array}$ & $\frac{\infty}{c}$ & & $\begin{array}{l}\text { ¿ } \\
\infty \\
\infty\end{array}$ & $\underset{A}{A}$ & in & E & & $\begin{array}{l}n \\
\infty \\
\infty \\
\infty\end{array}$ & 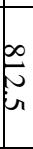 & 市 & $\begin{array}{l}\infty \\
\infty \\
+ \\
0\end{array}$ & \begin{tabular}{l}
0 \\
$\infty$ \\
\multirow{N}{*}{}
\end{tabular} \\
\hline $\begin{array}{l}\text { Gas (BCM) } \\
\text { (Billion } \\
\text { Cubic } \\
\text { Meters) }\end{array}$ & $\begin{array}{l}\vec{r} \\
i \tilde{n} \\
\stackrel{\infty}{\infty}\end{array}$ & $\frac{8}{6}$ & $N_{N}^{N}$ & 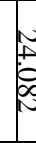 & & 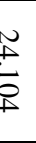 & 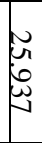 & E &  & & 记 & & $\underbrace{\omega}_{\tilde{N}}$ & $\underset{N}{\stackrel{N}{+}}$ & 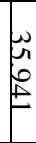 \\
\hline
\end{tabular}

Table 1 show that the production of oil is unstable. It is difficult to depend on this production in long-term development because anything could happen, and a drop in production or in prices could affect the government's vision for 2020. While gas production shows a slight increasing from 2000 to the end of 2012, there is no guarantee that this will continue, and it is expected to go down slightly after 2017. However, in 2012 the government covered the shortage of gas by importing around 5.4 million cubic meters from Qatar [4].

\subsection{Electrical Energy}

The total electricity net demand increased from 13,286,792 MWh in 2006 to $21,312,390 \mathrm{MWh}$ in 2011, an increase of more than $62 \%$. The electricity demand has been growing at a compounded average growth rate of $9.45 \%$ from 2006-2011, and it stood at 21,312,390 GWh in 2011. The peak demand at Muscat Interconnected System (MIS), is expected to grow at $8 \%$ per year, from $4,216 \mathrm{MW}$ in 2012 to $6,582 \mathrm{MW}$ in 2018, and in the Salalah system at $10 \%$ per year, from $394 \mathrm{MW}$ in 2012 to 689 MW in 2018. Moreover, the rural system will have an expected demand in 2018 of $685 \mathrm{MW}$.

Table -2: Estimation of electricity demand by system from 2012 to 2018

\begin{tabular}{|l|c|c|c|c|c|c|c|}
\hline & 2012 & 2013 & 2014 & 2015 & 2016 & 2017 & 2018 \\
\hline $\begin{array}{l}\text { MIS } \\
\text { System }\end{array}$ & 4,216 & 4,594 & 5,007 & 5,374 & 5,760 & 6,151 & 6,582 \\
\hline $\begin{array}{l}\text { Rural } \\
\text { System }\end{array}$ & 136 & 178 & 233 & 305 & 399 & 523 & 685 \\
\hline $\begin{array}{l}\text { Salalah } \\
\text { System }\end{array}$ & 394 & 433 & 480 & 531 & 584 & 636 & 689 \\
\hline
\end{tabular}

\subsection{Electrical Grid Network}

Gas production is more critical than crude oil, and it has a direct effect on Oman's economy and power production. Oman LNG and Qallat LNG are consuming a large amount of natural gas to produce LNG for export. Moreover, besides the use for LNG trains, the gas is largely utilised for reinjection into the oil reservoirs to maintain pressure and sustain oil 
production, while the remainder is being used in desalination plants and as fuel to generate power. The electricity supply industry in Oman is divided into the following three groups namely; Main Interconnected System (MIS), The Rural System and Salalah System.

\section{- Main Interconnected System (MIS)}

MIS is the main grid electrical network in the Sultanate of Oman and covers the governorates of Muscat, Al Batinah, Al Dakeliya, Al Buraimi, Al Dahera and Al Sharkia. It serves the majority of Oman's population (641,275 consumers), covering about $90 \%$ of the total electricity supplied in the Sultanate. The system connects seven main power plants using a network of $220 \mathrm{kV}$ and $132 \mathrm{kV}$ transmission lines. All companies under this system generate electricity from natural gas.

\section{- The Rural System}

Rural Area Electrical Company (RAECO) operates in areas where the transmission network of the MIS networks does not currently exist, which includes the Musandam, Al Wusta and Dhofar governorates. It generates, transmits and distributes power in its areas. It is also responsible for electrification of rural areas and funds this through a special mechanism in the sector law. Most of the electricity in RAECO is generated in diesel-fuelled facilities. Demand for electricity in RAECO areas will increase considerably when the development projects in the Al Dukm area and Masirah Island take off.

\section{- The Salalah Power System}

The Salalah power system, with voltage levels $33 \mathrm{kV}$ and 132 $\mathrm{kV}$, covers all the southern areas of the Sultanate of Oman (Dofhar governorate) and serves 63,698 consumers. This system uses both natural gas and diesel to generate electricity.

\subsection{Energy Management}

It is understood that the gas price for electricity power generation by the Public Authority of Electricity and Water is the equivalent of US\$ 1.5 /Mcubic feet. Petroleum Development of Oman (PDO) uses a price of $\$ 1 / \mathrm{m} \mathrm{ft} 3$ for its own gas use. There is a possibility that by the year 2020 the availability of gas may become limited.

The use of electric power is central to social development as well as commerce, industry, and fishing. Government policy is to bring the benefits of modernisation to all parts of the country. The Public Authority of Electricity and Water is responsible for the supply of power to all citizens. It manages a very effective programme of power generation and distribution and rural electrification of $90-94 \%$ of the population, with plans for further grid extensions and deployment of more diesel generating sets.

The government power supply involves the operation of both gas- and diesel-fuelled power stations with a transmission and distribution grid that covers most of the demand in the north of the country, and diesel power stations with local grids in the south. In the Petroleum Development of Oman (PDO) concession area, the PDO manages its own generation and distribution system using a mixture of gas and diesel generation. In addition to providing for its own use, the PDO sells power to the government to supply settlements in the concession area. A number of industrial concerns have their own captive power generation capacity [5].

\subsection{Management of Electricity Grid Network}

Royal Decree 78/2004, promulgated on 1 August 2004, the electricity sector was privatised and market structure was implemented as well as establishment of a regulator. Former structures were transferred to the following governmentowned companies [6]:

- Electricity Holding Company

- Oman Power and Water Procurement Company

- Oman Electricity Transmission Company

- Wadi Al Jizzi Power Company

- Al Ghubrah Power and Desalination Company

- Mazoon Electricity Company

- Majan Electricity Company

- Muscat Electricity Distribution Company

- Rural Areas Electricity Company

In terms of ownership, the companies represent a mix of government and private ownership, such as the AES Barka, SMN Barka, Al Kamil Power Company, United Power Company, Dhofar Power Company, Sohar Power Company, and Rusail Power Company.

These companies have a majority of private shareholders. Further electricity privatisation will be implemented through the sale of the government interest in some of the successor companies listed above [7].

The government's approach to privatisation is to allow $100 \%$ private ownership shareholdings through the Muscat securities market. Since 1 May 2005, the Authority has assumed full responsibility for the regulation of electricity and the related water sector. The followings activities in the sector are regulated [8]:

- Generation, transmission, distribution, export, import and supply of electricity

- Generation of electricity combined with desalination of water

- Generation of electricity co-located with desalination of water

- Central dispatching

- Development and/or operation of international interconnections

- Functions of Oman Power and Water Procurement Company (OPWP) 


\subsection{Electricity Tariff}

The current partial privatisation of power generation may indirectly increase the cost of energy supply to the consumer instead of least cost generation in a regulated environment. The higher unit costs at the rural and remote areas are expected due to the supply from off-grid diesel or petrol generators in remote locations. Figure 1 shows the electricity tariff structure in Oman for different types of customers.

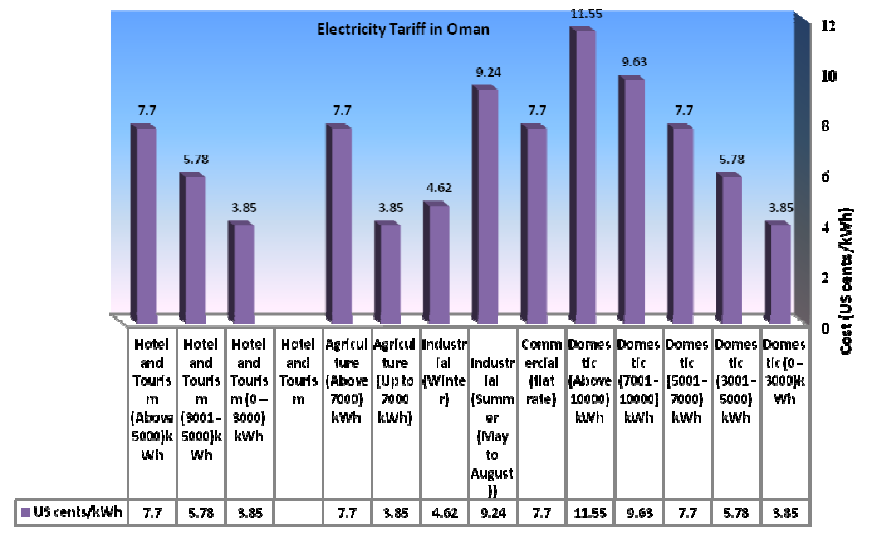

Fig -1: Government electricity tariff structure

\section{RENEWABLE ENERGY IN OMAN}

Renewable energy usually refers to those energies that do not pollute the environment and that can be recycled in nature. International experts have now categorised renewable energy as either traditional or new renewable energy. The traditional type includes giant hydropower and biomass burnt directly; the new renewable energy mainly refers to small hydropower, solar energy, wind energy, biomass energy, geothermal energy and ocean energy [9].

The fast economy development has led to increased energy requirements in the markets. However, the fossil fuel resources required for the generation of energy are insufficient. Moreover, fossil fuels directly affect climate change because of the effect of carbon emissions on the atmosphere. There are two main ways to reduce dependence on fossil resources: first, by reducing energy consumption by applying energy saving programmes focused on energy demand reduction and energy efficiency in the industrial and domestic spheres [10]; and second, by encouraging the cultivation of renewable energy, as this is an effective and practical choice to reduce carbon emissions

In 2007, the Authority for Electricity Regulation (AER), Oman announced that it would carry out a study in the field of renewable energy. The purpose of this study was to provide an overview of renewable energy sources in the Sultanate of Oman and the potential of these resources for electricity production. The study assessed the available renewable energy technologies and their technical suitability for use in the Sultanate. The study summarised the potential renewable energy sources in Oman are solar energy and wind energy, as these are the most abundant resources in the Sultanate. It also recommended the implementation of pilot projects and a feasibility study for electrical production using solar energy of 100-200 MW. This study was published in 2008 [11].

The level of solar energy density in Oman is among the highest in the world. There is a significant opportunity to develop solar energy resources throughout Oman and to provide sufficient electricity to meet all of Oman's domestic electricity requirements. High solar energy density is available in all regions of Oman, and it significantly increases during the summer season, which coincides with the peak periods of electricity demand in Oman. The areas of highest density are dessert areas, while the coastal area in the southern part of Oman has the lowest density.

The high ratio of sky clearness, at about 342 days per year, and the geographical location of Oman play an important role in creating the huge potential for solar electricity generation. The studies also show several locations in Oman with good projections for utilising wind energy for electricity production. For example, wind speeds in Dhofar, particularly in the mountains north of Salalah, are comparable to the recorded wind speeds at different production sites for electric wind power in Europe.

Adel Gastli and Yassine Charabi [12] found the majority of the land in Oman receives solar radiation ranging between $5500-6000 \mathrm{Wh} / \mathrm{m}^{2} /$ day and $2500-3000 \mathrm{Wh} / \mathrm{m}^{2} /$ day in July and January, respectively. However, solar radiation has critical environmental risks, mainly related to mineral dust deposition that can greatly reduce the profits of any solar energy system. The movement of a mineral dust particle, according to specific size and speed, is an efficient erodible agent that can affect the optical properties of any solar energy system; this means that it will require frequent cleaning using fresh water, which can be difficult because of the general scarcity of fresh water in the desert and semi-desert zones. This commodity should not be wasted on cleaning. Furthermore, they also studied the degree of contamination from mineral dust and tracked the exposure to dust constraint on the local scale using proxy open source data, considering recent NASA satellite data from the Multi-angle Imaging Spectro-Radiometer (MISR). MISR provides significant information about dust emission, transport, concentration and property evolution using Aerosol Optical Depth (AOD) [13].

They used MISR AOD data sets to appraise the dust risk map for solar energy system sitting and implementation in Oman. The suggested approach is very practical in pointing out the degree of contamination with dust in space and time. Consistent results between dust emission sources, MISR AOD 
and the climate synoptic conditions indicate that large areas of Oman are highly affected by mineral dust, in terms of the concentration and occurrence of dust storm events throughout the year, and due to their proximity to emission sources they are not suitable for the implementation of solar energy systems. So, it is possible to conclude that areas with high dust concentrations are not suitable for solar energy applications because they would require more frequent cleaning and therefore consume large amounts of water. As a result, it is important to include the annual average AOD as an important constraint during the sitting of solar energy systems. In a case study on Oman, when they considered this constraint it gave a reduction of $64 \%$ from the most suitable areas.

Moreover, they are using GIS-based spatial fuzzy multicriteria evaluation to assist the solar energy resource and site suitability for large PV farms implementations. This will be affected by different factors, which are classified in three main categories: technical, economic and environmental. These factors depend on the geographical location, biophysical attributes and socio-economic infrastructure of the country under study [14]. They developed the first geographical mapping models to locate the most appropriate sites for different PV technologies in Oman using MCA. They combined the different weights of all the factors listed above. The most isolated areas were predisposed to high suitability. They found that all types of PV technologies can produce huge amounts of electricity in Oman.

They also made a GIS assessment of a large CSP plant in Duqum in Oman using GIS tools [15]. They calculated the solar radiation on a DEM using Arc Map. They found that the highest solar radiation per day was $8217 \mathrm{Wh} / \mathrm{m}^{2} /$ day during the month of June (summer solstice) and the lowest one was $4059 \mathrm{Wh} / \mathrm{m}^{2} /$ day in December (winter solstice).

They also worked with Slim Zekri to investigate the potential for implementing combined electric power and seawater desalination plants using concentrated solar power technologies for Wilayat Duqum in Oman [16]. They concluded that seawater desalination will have a major share on freshwater supply that will be reasonable for Duqum in particular and Oman in general. Moreover, if concentrating solar power (CSP) is used for an energy supply, it will be a domestic energy source and will not have a major environmental impact. It was found that the amount of solar radiation in the Duqum region is very promising, and if CSP is used, it will help provide a sufficient amount of both electricity and desalinated water. Based on GIS solar radiation calculations, geographical topology and the master development plan of the Duqum region, the most appropriate site for a CSP plant is in close proximity to the coast in an industrial area.

In [17], they developed a Matlab/SIMULINK for the solar PV cell modules and array. The model is based on the fundamental circuit equation of a solar PV cell, taking into account the effects of physical and environmental parameters, such as the solar radiation, and validated experimentally using the highly efficient PVL-124 solar laminate panel. This model would provide a tool for predicting the behaviour of a solar PV cell, module and array under climate and physical parameter changes and also as a photovoltaic generator in the framework of the Sim-power-System Matlab/SIMLINK toolbox in the field of solar PV power conversion systems.

In [18], they assessed wind power cost per $\mathrm{kWh}$ of energy produced using four types of wind machines at 27 locations on an hourly basis from 2000-2009. The study found that the energy cost is low in the southern and middle region of Oman and high in the northern region. It also developed wind duration curves for 27 locations, which is beneficial in finding the duration and availability of the wind in different areas in terms of the useful range of wind speed.

However, in [19], they investigate five years of hourly wind data from 29 weather stations. They used different criteria, including theoretical wind power output, vertical profiles, turbulence and peak demand fitness. They acknowledged the potential location for wind energy applications in Oman. They considered air density and roughness length when calculating the wind power density potential. Moreover, they used a seasonal approach to identify the potential in different seasons. They introduced a scoring approach in order to classify the potential sites based on five factors: wind power output factor, vertical profile factor, wind speed turbulence factor, wind diurnal variation factor and peak demand fitness factor. In [20], they evaluated the performance of the Numerical Weather Prediction (NWP) model data for wind energy application in Oman with a comparison to satellite data. Moreover, they used a nested ensemble NWP approach, which leads to more accurate resource assessment, wind turbine micros ting and short-term energy forecasting.

In [21], they implemented the NWP models and the multicriteria decision technique (MCDM) on Masirah Island as a case study. The resource assessment of the island was based on the mean wind speed and wind power distribution over the entire island at different heights. They scored the locations using MCDM model across the island based on their suitability for wind energy applications. A wind farm land suitability index using multi-criteria analysis was applied, and it consisted of a set of alternative locations and a set of selection criteria. Using the analytical hierarchy process with an ordered weight averaging (AHP-OWA) aggregation function they derive the wind farm land suitability index.. Different selection criteria, such as distance to road, terrain slope, urban area, historical locations, wildlife and natural reserves, wind power density, energy demand matching, percentage of sustainable wind, turbulence intensity and sand dunes were considered. 


\section{ISSUES AND BARRIERS TO RE DEPLOYMENT}

Renewable Energy technologies possess many long-term benefits that are often overlooked. These benefits include energy security, job creation, business opportunities, sustainable development and prevention of global warming [22].

Advancing of RE development is an effective approach for addressing energy security and climate change. Currently, the U.S., Japan, Brazil and other countries have listed the development of $\mathrm{RE}$ as an important strategy for the future [23]. Most research in Brazil on renewable energy policy evolution is related to the evolution of biomass energy policies, while research in Russian renewable energy policy evolution is insufficient and limited to policies on the diffusion and transfer of renewable energy technologies. In China, research is focused on two aspects: assessing the effect of implementation based on the type of policy and analysing renewable energy evolution policies according to energy types [24].

RE development is dependent on political support. As long as $\mathrm{RE}$ is not financially and economically competitive in the liberalised market, there is a need for political support. However, this energy is expected to become progressively cheaper in the near future.

A positive investment climate, strong property rights and low tax regimes, with established participation in the power sector from leading international firms, will certainly provide more incentives for RE applications in the country. It is important to receive non-renewable energy policy support. In addition, laws governing power generation regulation shall provide more flexibility and incentives for RE. For instance, the government needs to develop policies to support investors in large-scale solar plants and also to support/increase market opportunities for small-scale solar photovoltaic applications.

Furthermore if the development of the appropriate regulatory and financial framework is not accelerated, neighbouring countries, such as the United Arab Emirates (UAE), may capture first-mover advantages and develop regional expertise because of their recently announced subsidies and incentives for solar photovoltaic installations [25].

Therefore it is urgently recommended that efficient local, regional and international networking capabilities should be established in order to benefit from others best practices and to acquire knowledge and expertise faster and more efficiently. Also, a local research and development infrastructure has to be established and developed, which will involve collaboration between different constituents, including academia, industry and government.
The deployment of renewable energy in Oman has grown up in a very slow pace for the past few years. This is related to the fact that there are no clear plans for the future of energy in Oman, as there is no strategic plan for renewable energy, nor is there a clear target. Following are some of the reasons for the slow RE development in Oman:

\section{Lack of coordination and consistency in policy}

Since the first study done by PDO in 2000 [6], there has been no progress, and there has only been one new study, in 2008, by the Authority for Electricity Regulation [11]. The country has been slow in implementing the recommendations of the 2008 study. This is because the responsibility for Oman renewable energy business goes to many sectors, such as Petroleum Development Oman (PDO), the Authority of Electricity and Water, the Authority for Electricity Regulation, Oman Power and Water Procurement and the RAECO. This makes it difficult to provide consistent energy policies. Furthermore, energy policies in different fields lack coordination, making it difficult to form an effective long-term system to support sustainable RE development.

\section{No encouragement for $R E$}

The government has developed policies in renewable energy in 2008, but it is still unable to compete with fossil energy and its development depends upon the government support. The government provides subsidies for fossil energy has hampered the development and support of RE. In order to promote RE, a research task could be commissioned to establish in greater detail the locations and strengths of local wind and solar resources. A task force or forum might bring together experience and ability to provide a powerful initiative. It would be a prestigious body through which Oman would be able to develop its own renewable energy resources and gain international recognition in this growing world business sector.

\section{No financing system for renewable energy projects}

There is a high initial unit cost of equipment and maintenance, as a result of small initial order sizes, novel equipment, and the small number of units in the field to maintain. The industry could be kick started with funding for the necessary equipment, working capital, and initial overheads. Experienced management would be needed.

Inadequate investment in technical research and development for renewable energy

Renewable energy is a technique-intensive and fund-intensive industry. It is a requirement for stable and rapid development. By the end of 2011, there had been no investment in renewable energy allocated in the budget. A training programme for all levels of design and operation might be established to focus on the operation and support of immediately deployable technologies (of small-scale PV and wind-powered water pumping). This programme might then be expanded to provide the research, development and 
demonstration capabilities needed to support a developing business sector. This design and development capability might also be applied to providing a demonstration and testing service for international manufacturers.

\section{WAY FORWARD}

With its strong solar resources and existing universities, Oman has an opportunity to establish a world position through the provision of a professional demonstration and monitoring capability for international technology providers, as well as to carry forward the further development of relevant technologies. Such an initiative would involve the development of an advanced professional skills base in science and engineering. It might logically be expanded to provide a specialisation in modern solar-efficient architecture and energy management.

The success of the RE deployment by the Oman's government will depend on how well the regulatory policies, fiscal incentives and the Public Financing are being carried out as shown in Figure 2.

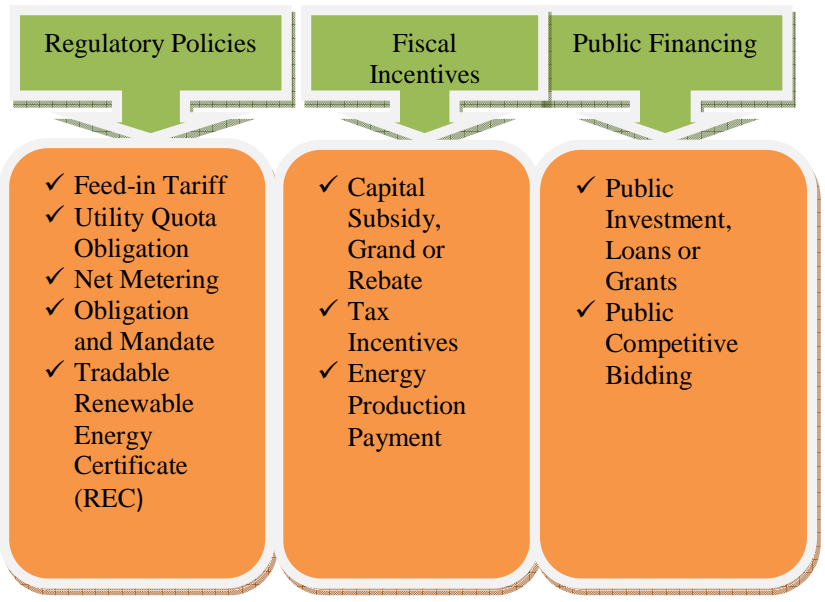

Fig -2: The renewable energy policy network (REN21)

\section{CONCLUSION}

There is an great opportunity for Oman to utilise renewable energy for commercial advantage, as solar and wind energy technologies in particular can achieve more competitive costs. The effective use of these technologies would require the development of a suitable skills base and provide the opportunity to develop a local level of manufacturing, each involving an increase in the level of skilled employment. It would contribute to the extension and diversification of both the economy and energy sources. It would be in line with the objectives of Oman Vision 2020. It would also help Oman establish a world position in this energy sector by providing a professional demonstration and monitoring capability for technology providers, as well as helping to carry forward the development of relevant technologies.

\section{REFERENCES}

[1]. Ministry of National Economy, Oman. Final Results of Census 2010. Supreme Council for Planning, National centre for Statics and Information 2010. http://www.moneoman.gov.om/viewPublication.aspx?i $\mathrm{d}=781$.

[2]. Ministry of National Economy, Oman. The development experience and investment climate, $6^{\text {th }}$ edition. National Centre for Statics and Information 2008.

http://www.moneoman.gov.om/PublicationAttachment/ Oman

[3]. Mine Tukenmez and Erhan Demireli. (2012), ‘ Renewable energy policy in Turkey with the new legal regulations', Renewable Energy, Vol. 39, pp. 1-9

[4]. Zhang P, Yang Y, Shi J, Zheng Y, Wang L, Li X. Opportunities and challenges for renewable energy in China. Renewable and Sustainable Energy Reviews 2011;13:439-449

[5]. Authority of electricity regulation, Oman (Annual Reports).2009; http:/www.aer-oman.org.

[6]. Buckley JR, Holmes EB. Oman renewable energy for sustainable development, Sustainable Energy Marketing Company - Oman's planning Vision 2020. PDO executive summary 2000.

[7]. Authority of electricity regulation, Oman. Annual Report, 2010; http://aer-oman.org.

[8]. Authority of electricity regulation, Oman. Annual Report, 2011; http://aer-oman.org/ index.php? option=com_content $\&$ view $=$ article $\&$ id $=87 \&$ Itemid $=14$ 6

[9]. Public Authority for Electrical and Water, Oman. Renewable energy in Oman ,summary report,2012; http://www.paew.gov.om.

[10]. Banos R, Manzano-Agugliaro F, Montoya FG, Gil CI, AlCayde A, Gomez J. Optimization methods applied to renewable energy and sustainable energy: A review. Renewable and Sustainable Energy Reviews 2011;15:1753-1766.

[11]. Authority of electrical regulation, Oman. Renewable energy resources in Oman. 2008. http://aer-oman.org.

[12]. Al-Yahyai S, Charabi Y, Gastli A, Al-Alawi S. (2010), - Assessment of wind energy potential locations in Oman using data from existing weather stations', Renewable and Sustainable Energy Reviews 2010;14:1428-1436.

[13]. Gastli A, Charabi Y. Solar electricity prospects in Oman using GIS-based solar radiation maps. Renewable and Sustainable Energy Reviews 2010;14:790-797.

[14]. Charabi Y, Gastli A. Spatio-temporal assessment of dust risk maps for solar energy systems using proxy data. Renewable Energy 2012;44:23-31. 
[15]. Charabi Y, Gastli A. GIS assessment of large CSP plant in Duqum, Oman. Renewable and Sustainable Energy Reviews 2010;14:835-841.

[16]. Gastli A, Charabi Y, Zekri S. GIS-based assessment of combined CSP electric power and seawater desalination plant for Duqum-Oman. Renewable and Sustainable Energy Reviews 2010;14:821-827.

[17]. Ugwuoke PE, Okeke CE. Statistical assessment of average global and diffuse solar radiation on horizontal surfaces in tropical climate. International Journal of Renewable Energy Research 2012;2(2):269-273.

[18]. Salmi T, Bouzguenda M, Gastli A, Masoudi A. Matlab/Simulink based modeling of solar photovoltaic cell. International Journal of Renewable Energy Research 2012;2(2):213-218.

[19]. Al-Yahyai S, Charabi Y, Al-Badi A, Gastli A. Nested ensemble NWP approach for wind energy assessment. Renewable Energy 2012;37:150-160.

[20]. Al-Yahyai S, Charabi Y, Gastli A, Al-Alawi S. Wind resource assessment using numerical weather prediction models and multi-criteria decision making technique: case study (Masirah island, Oman),( Under preparation to publish).

[21]. Al-Yahyai S, Charabi Y, Al-Badi A, Gastli A. Wind farm land suitability indexing using multi-criteria analysis. Renewable Energy 2012;44:80-87.

[22]. Huiming Z, Lianshui L, Jie C, Mengnan Z, Qing W. Comparison of renewable energy policy evolution among the BRICs. Renewable and Sustainable Energy Reviews 2011. RSER-1465. doi:10.1016/j.rser.2011.07.063

[23]. Martin NJ, Rice JL. Developing renewable energy supply in Queensland, Australia: A study of the barriers, targets, policies and actions. Renewable Energy 2012:1-9. doi: 10.1016/j_renene.2012.01.006

[24]. Yiping F. Economic welfare impacts from renewable energy consumption: the China experience. Renewable and Sustainable Energy Reviews 2011;15:5120-5128.

[25]. Al-Badi AH, Malik A, Gastli A. Sustainable energy usage in Oman- Opportunities and barriers. Renewable and Sustainable Energy Review 2011;15:3780-3788.

[26]. Zhang P, Yang Y, Shi J, Zheng Y, Wang L, Li X. Opportunities and challenges for renewable energy policy in China. Renewable and Sustainable Energy Review 2009;13:439-449.

\section{BIOGRAPHIES}

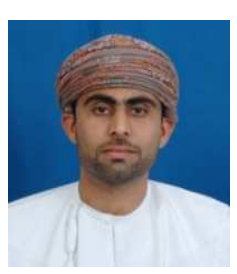

Al Hatmi Yousof, is currently pursuing his $\mathrm{PhD}$ in Universiti Tenaga Nasional. He completed his M.Sc. in Mechanical Engineering and B.Eng. in Mechanical and Industrial Engineering at University of Sultan Qaboos, Oman. His research interest is Renewable Energy

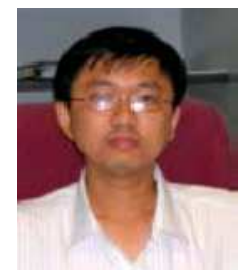

Tan Ching Sin is currently the Head of Energy Security of the Institute of Energy Policy and Research (IEPRe), UNITEN. $\mathrm{He}$ holds a MSc and $\mathrm{PhD}$ (Electrical Engineering), from University of Strathclyde, UK and B.Eng in Electrical Engineering from Universiti of Teknologi Malaysia, Malaysia. His current research interests are Energy Security, Renewable Energy, Energy Efficiency and deregulation. 